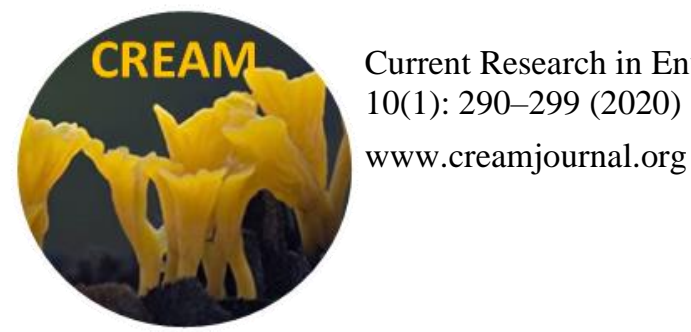

\title{
Some noteworthy records of Helvella from Turkey based on morphology and DNA sequence data
}

\author{
Kaygusuz $\mathbf{O}^{1 *}$, Türkekul $\dot{\mathbf{I}}^{2}$ and Battistin $\mathbf{E}^{3}$ \\ ${ }^{1}$ Isparta University of Applied Sciences, Atabey Vocational School, Department of Plant and Animal Production, \\ 32670, Isparta, Turkey \\ ${ }^{2}$ Gaziosmanpaşa University, Faculty of Science and Arts, Department of Biology, 60010, Tokat Turkey \\ ${ }^{3}$ Natural History Museum, Corso Italia, 63, Valdagno (VI) 36078, Italy
}

Kaygusuz O, Türkekul İ, Battistin E 2020 - Some noteworthy records of Helvella from Turkey based on morphology and DNA sequence data. Current Research in Environmental \& Applied Mycology (Journal of Fungal Biology) 10(1), 290-299, Doi 10.5943/cream/10/1/27

\begin{abstract}
In the present study, current information based on morphological characters and DNA sequence (nrITS) data is given on some uncommon or noteworthy Ascomycetes species collected from different geographic regions of Turkey. First phylogenetic analysis based on nrITS data of Helvella fibrosa and H. macropus the rare and little-known species was performed in Turkey by this study. Also, the nrITS sequence of $H$. fibrosa was uploaded to current databases for the first time. Detailed morphological description, macro photographs and detailed drawings of micro structures of the two species studied have been presented, and the ecology and distributions of each species has been given.
\end{abstract}

Key words - ecology - Mediterranean macrofungi - Pezizales - phylogeny - rare species taxonomy - Turkish mycobiota

\section{Introduction}

Fungi are the second largest group of eukaryotic organisms in the world, with approximately 100000 species described (Kirk et al. 2008). The total number of species is estimated to be between 1.5 and 5.1 million (Hawksworth 1991, 2001, O'Brien et al. 2005, Blackwell 2011). According to various studies, the Ascomycota constitute about half of all fungal species (Bass \& Richards 2011). In addition to genera with a simple structure such as Peziza Dill. ex Fr. and Aleuria Fuckel (orange peel fungus) with their characteristic cup-shaped apothecia, the Pezizales group of Ascomycota includes other genera producing more complex and larger ascocarps like the wellknown Morchella Dill. ex Pers., Helvella L. and Tuber P. Micheli ex F.H. Wigg. (Larsen 1980, Hansen \& Pfister 2006).

Members of the Helvella genus generally are characterized by auriculoid, cupulate to saddleshaped apothecia varying from white to black in color, the presence of ribs on the stipe and the structure of their ascospores (Dissing 1966a, b, Abbott \& Currah 1997). So far, approximately sixty Helvella with these characteristics have been described (Wijayawardene et al. 2017). A large number of new entities belonging to Helvella have been described from different parts of the world thanks to recent multigenic DNA studies (Nguyen et al. 2013, Hwang et al. 2015, Zhao et al. 2015, Tibpromma et al. 2017, Skrede et al. 2017). Many Helvella taxa are widely distributed in shadow areas of deciduous and coniferous forests (Wang \& Chen 2002, Zhao et al. 2015). Members of this 
genus have been widely reported from land biomes in Europe, North America, Asia and Australia, but little is as yet known of their status in tropical areas (Sesli \& Denchev 2008, Nguyen et al. 2013, Solak et al. 2015, Hwang et al. 2015, Skrede et al. 2017, Hansen et al. 2019, Uzun 2019, Løken et al. 2020).

Helvella fibrosa was previously recorded from the Kahramanmaraş Province in the Mediterranean Region (Kaya 2009) and Helvella macropus from Trabzon Province in the Black Sea Region of Turkey (Akata \& Kaya 2012). Our collections of H. fibrosa is given from İstanbul Province and H. macropus is recorded from Artvin Province which are new locality records of these macrofungi (Sesli \& Denchev 2008, Solak et al. 2015). The purpose of this study is to provide up-to-date information on rare and noteworthy taxa $H$. fibrosa and $H$. macropus identified from different geographical regions of Turkey, based on their morphology and DNA sequence (nrITS) data.

\section{Materials \& Methods}

\section{Specimens and morphological studies}

The field works were undertaken in different geographical regions of Turkey between the years 2013 and 2015. Photographs of the fruiting bodies were taken in their natural habitats and their ecological notes were recorded.

The macroscopical descriptions and images of the ascomata were obtained by observation of fresh or dried specimens. For microscopical analyses, the dried materials were rehydrated in distilled water and $3 \% \mathrm{NaOH}$ or $5 \% \mathrm{KOH}$, and subsequently stained with Congo Red or Melzer's solution. The following abbreviations are used in the descriptions: $\mathrm{L}^{\mathrm{m}}$ : for the average length of all the measured ascospores, $\mathrm{W}^{\mathrm{m}}$ : for the average width of all the measured ascospores, $\mathrm{Q}$ : for the quotient of length and width of all the measured ascospores, and $\mathrm{Q}^{\mathrm{m}}$ : for the average of all calculated $\mathrm{Q}$ values for all ascospores measured. At least thirty mature ascospores from each ascoma were measured. The specimens were deposited at the fungarium of Isparta University of Applied Sciences (Turkey).

\section{DNA extraction, PCR amplification and sequencing}

Total genomic DNA was extracted from fresh or dried materials using the ZR Fungal/Bacterial DNA MiniPrep kit (Zymo research, Irvine, CA, USA). Protocols for DNA extraction, PCR and sequencing were the same as those outlined in Kaygusuz et al. (2019). PCR and sequencing of the complete internal transcribed spacer (ITS) region from the ribosomal DNA (rDNA) was performed using ITS1F and ITS4 (White et al. 1990, Gardes \& Bruns 1993). Primers ITS1F/ITS4 were used to amplification, using the touchdown PCR protocol described in Kaygusuz et al. (2019). All PCR products were sequenced in Sanger DNA sequencing service (Source Bioscience, Berlin, Germany), with the same primers used in the PCR reactions. The raw DNA sequencing files were edited with Chromas Lite 2.1.1 (http://technelysium.com.au/wp/chromas/) and assembled with BioEdit 7.2.5 (Hall 1999). The edited sequences were then used for BLAST searches in GenBank (www.ncbi.nlm.nih.gov). The newly generated sequences were deposited in GenBank with corresponding accession numbers (MF228805 and MF228806).

\section{Sequence alignment and phylogenetic analyses}

For this study, two new sequences of nrITS were generated. Further twenty-four related sequences used in phylogenetic analysis were downloaded from the NCBI (National Center for Biotechnology Information, Rockville Pike, Bethesda MD, USA) database. All sequences were aligned by MAFFT (version 7.110) programs (Katoh \& Standley 2013). In addition, final alignments were manually corrected via BioEdit and MEGA X v.10.0.5 (Kumar et al. 2018). In both Bayesian Inference (BI) and Maximum Likelihood (ML) analyses, Dacrymyces chrysospermus Berk. \& M.A. Curtis (AB712452) was used as the outgroup taxon. 
Phylogenetic tree inference was performed for the ITS dataset by both ML and BI methods. The ML analysis was performed through the Cipres Science Gateway v.3.3 interface (http://www.phylo.org/portal2/) (Miller et al. 2010) using RAxML v.8.2.10 (Stamatakis 2014) employing the GTRGAMMA model with 1000 ML bootstrap replicates and default settings for other options. The BI was carried out using Markov Chain Monte Carlo (MCMC) methods with MrBayes version 3.2.2 (Ronquist et al. 2012). Markov chains were run for $10^{6}$ generations, saving a tree every $1000^{\text {th }}$ generation, with two runs per analysis. The initial $25 \%$ trees recovered were excluded as a burn-in, and a 50\% majority consensus tree of the remaining trees was then used to calculate the posterior probabilities (PP) of the group. The phylogram inferred from both analysis were displayed with FigTree v.1.4.3 (Rambaut 2016).

\section{Results}

\section{Molecular phylogeny}

Our phylogenetic analysis has involved on twenty-six nucleotide sequences. The final dataset contained 1141 nucleotide sites. The resulting phylogram with the lowest BIC (Bayesian Information Criterion) value (-16015.88) and highest log likelihood (-7976.45) are presented. We selected the topology resulting from the first iteration to present here (Fig. $1,-\operatorname{In} L=7745.88$ ).

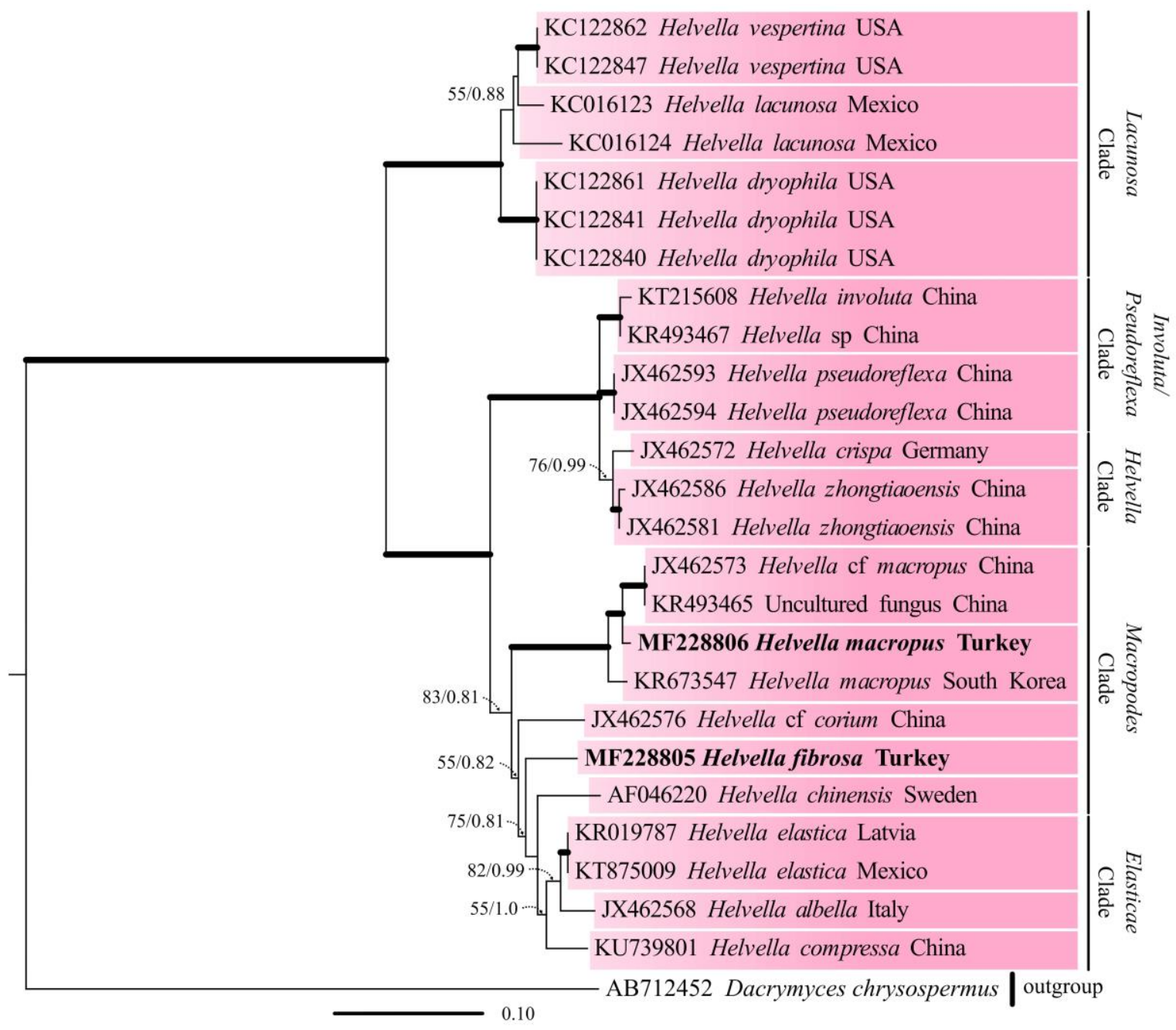

Fig. 1 - Phylogenetic tree obtained from the maximum likelihood analysis of the ITS-rDNA dataset. Dacrymyces chrysospermus (AB712452) was used as outgroup. Support values (Maximum likelihood bootstrap - MLB $\geq 55 \%$ / Bayesian posterior probability - BPP $\geq 0.80$ ) are shown above individual branches. The branches are bold when MLB $\geq 90 \%$ and BPP $\geq 0.95$. Newly generated sequences from Turkey are marked in bold. 
The phylogram obtained using Bayesian (MCMC) method, showing the Bayesian posterior probability (BPP), displayed similar topology to the phylogram obtained using Maximum likelihood (ML) analyses in RAxML. Therefore, only the ML phylogenetic tree with both Maximum likelihood bootstrap (MLB) values and Bayesian posterior probability (BPP) have been indicated in Fig. 1.

The tree identified by ML analysis of Helvella yielded five major clades (Fig. 1): (1) Lacunosa clade $(\mathrm{MLB}=100 \%, \mathrm{BPP}=1.0)$ formed by $H$. vespertina N.H. Nguyen \& Vellinga, $H$. lacunosa Afzel. and H. dryophila Harmaja, (2) Involuta/Pseudoreflexa clade (MLB $=99 \%, \mathrm{BPP}=$ 1.0) consisting of $H$. involuta Q. Zhao, Zhu L. Yang \& K.D. Hyde and H. pseudoreflexa Q. Zhao, Zhu L. Yang \& K.D. Hyde, (3) Helvella clade (MLB =76\%, BPP = 0.99) composed of H. crispa (Scop.) Fr. and H. zhongtiaoensis J.Z. Cao \& B. Liu, (4) Macropodes clade (MLB $=83 \%$, BPP = 0.81) formed by $H$. cf. macropus, H. macropus (Pers.) P. Karst., H. cf. corium (O. Weberb.) Massee, H. fibrosa (Wallr.) Korf and H. chinensis (Velen.) Nannf. \& L. Holm, and (5) Elasticae clade $(\mathrm{MLB}=55 \%, \mathrm{BPP}=1.0)$ composed of $H$. elastica Bull., $H$. albella Quél. and $H$. compressa (Snyder) N.S. Weber. Phylogenetic results showed that the most basic phylogenetic branch of the five lineages described in Helvella was formed by the Lacunosa clade. Also, sister group relationships were shown both between the Involuta/Pseudoreflexa and Helvella clades and between the Macropodes and Elasticae clades. Collections of H. macropus from Turkey and South Korea and samples of $H$. cf. macropus from China grouped together, forming a well-supported branch $(\mathrm{MLB}=100 \%, \mathrm{BPP}=1.0)$. A collection of $H$. fibrosa recorded from Turkey is located on a well-supported branch in this clade $(\mathrm{MLB}=75 \%, \mathrm{BPP}=0.81)$. Also, this species forms a group close to $H$. cf. corium and $H$. chinensis. There was no data in GenBank to compare ITS sequences obtained from $H$. fibrosa, and so the status of this species within the Macropodes clade has not yet been entirely clarified.

\section{Taxonomy}

Helvella fibrosa (Wallr.) Korf, Mycotaxon 103: 311. 2008.

Fig. 2

Facesoffungi number: FoF 08726

Basionym - Peziza fibrosa Wallr., Fl. Crypt. Germ. 2: 498. 1833.

Synonyms - Macropodia fibrosa (Wallr.) Sacc., Syll. Fung. 8: 160. 1889; Octospora villosa Hedw., Descr. Micro-anal. Musc.: 2: 54. 1789; Peziza macropus var. villosa (Hedw.) Pers., Syn. Meth. Fung. 2: 646. 1801; Peziza macropus $\beta$ (var.) hirta (Hedw.: Fr.) Fr., Syst. Mycol. 2: 57. 1822; Fuckelina villosa (Hedw.) Kuntze, Revis. Gen. Pl. 2: 852. 1891; Cyathipodia villosa (Hedw.) Boud., Icon. Mycol., liste prélim.: 2. 1904; Leptopodia villosa (Hedw.) Arnould, Bull. Soc. Mycol. France 9: 111. 1893; Helvella villosa (Hedw.) Dissing \& Nannf., Svensk Bot. Tidskr. 60(2): 330. 1966; Helvella dissingii Korf, Mycotaxon 31(2): 381. 1988.

Ascoma 5-13 $\mathrm{mm}$ high. Apothecia 3-6 mm high, 3-4 mm wide, cup-shaped at first, becoming saddle-shaped to irregularly lobed, typically initially laterally compressed, sometimes with a deflexed margin, pinched in at the apex; hymenium pale grey or dark gray when young, fading to greyish-brown to pale gray, smooth; exterior surface light-grey to pale-grey or pearl grey, very hairy, densely pubescent. Stipe 4-12 mm long, 1-2 mm broad, central, cylindrical, solid, hairy, densely pubescent, whitish to cream, becoming creamy when dried, basal mycelium white. Context very thin and fragile, light to pale gray. Smell and Taste indistinct. Spore print white.

Ascospores (12.0-)14.3-16.2(-18.0) $\times(8.4-) 10.5-11.9(-12.2) \mu \mathrm{m}, \mathrm{L}^{\mathrm{m}} \times \mathrm{W}^{\mathrm{m}}=15.3 \times 11.2$ $\mu \mathrm{m}, \mathrm{Q}=(1.2-) 1.3-1.5(-1.6) \mu \mathrm{m}, \mathrm{Q}^{\mathrm{m}}=1.4 \mu \mathrm{m}$, ellipsoid, uniguttulate, uniseriate, smooth, hyaline, thin-walled. Asci 200-270 $\times 13.5-16.5 \mu \mathrm{m}$, subcylindrical to clavate, operculate, hyaline, inamyloid, uniseriate, 8-spored, gradually enlarged towards apex, narrowed below. Paraphyses 2-4 $\mu \mathrm{m}$ wide, gradually enlarged at the apex 3-6 $\mu \mathrm{m}$, clavate, slender, slightly exceeding the asci, septate, thin-walled, hyaline to pale brown. Medullary excipulum 250-420 $\mu \mathrm{m}$ broad, of textura intricata, composed of interwoven, branching, septate, hyaline, thick-walled hyphae 3-7 $\mu \mathrm{m}$ broad. 
Ectal excipulum 180-270 $\mu \mathrm{m}$ broad, of textura angularis, hyphae hyaline, outermost cells $18-36 \times$ 10-19 $\mu \mathrm{m}$, end cells clavate to subclavate, with long fascicled hyphae, slightly thick-walled.
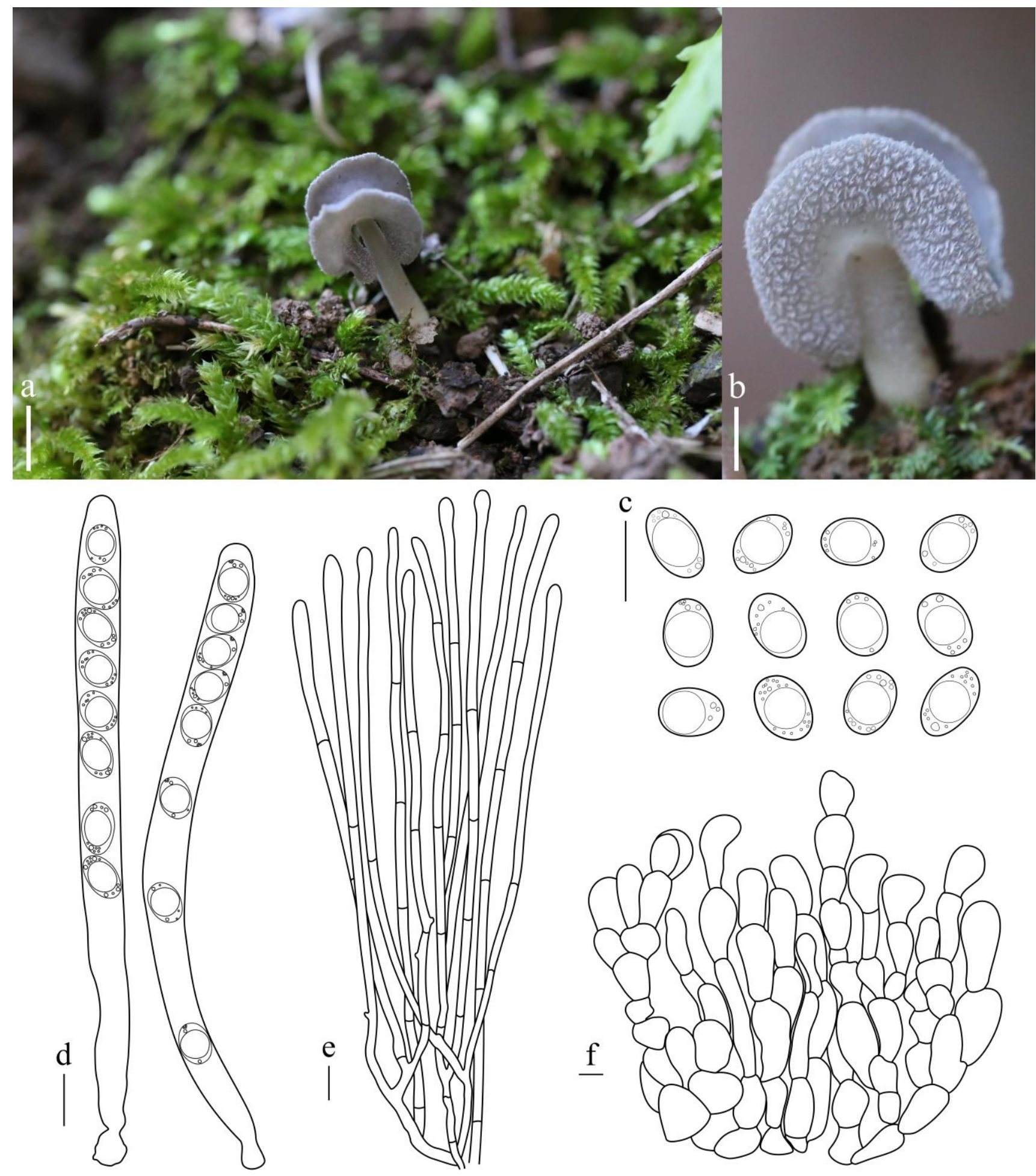

Fig. 2 - Helvella fibrosa (OKA2100). a - b Fresh apothecia, on natural substrate. c Ascospores. $\mathrm{d}$ Asci. e Paraphyses. f Ectal excipulum of apothecia. Scala bars: $\mathrm{a}=5 \mathrm{~mm}, \mathrm{~b}=1 \mathrm{~mm}, \mathrm{c}, \mathrm{d}=20$ $\mu \mathrm{m} ; \mathrm{e}, \mathrm{f}=10 \mu \mathrm{m}$. Photographs and line drawings by O. Kaygusuz.

Specimen examined - TURKEY, İstanbul Province, Şile district, near Saklı Lake, under or in the close vicinity of Quercus petraea (Mattuschka) Liebl., on wet soil among mosses, elev. $75 \mathrm{~m}$, 23.11.2013, coll. and det. by O. Kaygusuz, OKA2100 (MF228805, OKA-100). 
Ecology - Solitary or in scattered small groups on the ground or amongst moss, in temperate deciduous mixed forests, on damp to moist, mostly acidic soils, generally on slopes or hills derived from rocks which are rich in nutrients, fruiting in temperate periods between late October and early November, mainly present at elevation of under $100 \mathrm{~m}$. Reported under or in the close vicinity of Quercus petraea.

Comments - Characteristic features such as an apothecia varying from blackish to grey in color, a cup-shaped apothecia, a thin stipe and lower parts with a pubescent form are useful in identifying members of the genus Helvella. Of these, Helvella fibrosa has been recorded from different regions of the world and is seen to have a wide distribution. However, this species has long been confused with $H$. macropus, and wrong identifications have been made. Korf (2008) summarized the outlines of the historical name changes of $H$. fibrosa, and how its current name has been accepted. H. fibrosa is morphologically similar to H. macropus, but they can be distinguished by the darker hymenium and less villose apothecia surface of $H$. fibrosa (Skrede et al. 2017). Also, the ascospores of $H$. fibrosa are ellipsoidal and not acuminate.

Helvella fibrosa may be confused with $H$. cupuliformis Dissing \& Nannf. because of its cupshaped apothecium and straight and round stipe. Fresh specimens of these two species can be distinguished by hymenium color, which varies from grey or dark greyish-brown to dark brown in H. fibrosa, and from pale brown to yellowish brown in H. cupuliformis (Dissing 1966a, b). Dried specimens of $H$. fibrosa can be distinguished from $H$. cupuliformis by its longer and less sturdy stipe. Also, $H$. fibrosa has rather narrower spores than $H$. cupuliformis.

Under adverse environmental conditions, $H$. fibrosa can be confused with $H$. corium, $H$. didicusana L. D. Gómez, H. solitaria P. Karst., and H. rivularis Dissing \& Sivertsen. However, they can be distinguished from $H$. fibrosa by the slightly longer ascospores and blacker apothecium of $H$. corium (Dorjey et al. 2013), the smaller ascospores $(6-14 \times 6-8 \mu \mathrm{m})$ of $H$. didicusana (Van Vooren 2014, Landeros et al. 2015), the ribbed stipe of H. solitaria (Beug et al. 2014), and the small apothecium and slightly larger ascospores $(17-20 \times 11-13 \mu \mathrm{m})$ of $H$. rivularis (Van Vooren 2014).

According to the present phylogenetic tree, H. fibrosa is phylogenetically closely related to but distinct from $H$. macropus, $H$. cf. macropus $H$. cf. corium and $H$. chinensis based on the ITS data. In addition, the result that $H$. fibrosa grouped with collections of $H$. cf. corium from China and $H$. chinensis from Sweden as a whole gets good statistical support, 75\% of bootstrap and 0.81 bayesian PP support. The ITS sequences obtained from $H$. fibrosa in this study were uploaded to current databases for the first time. Because of the lack of data in GenBank with which to compare $H$. fibrosa, the position of this species in the Macropodes clade has not been completely elucidated.

Helvella macropus (Pers.) P. Karst., Bidr. Kann. Finl. Nat. Folk 19: 37, 1871.

Fig. 3

Facesoffungi number: FoF 08727

Basionym - Peziza macropus Pers., Ann. Bot. (Usteri) 15: 26.1795.

Synonyms - Peziza macropus Pers., Ann. Bot. (Usteri) 15: 26. 1795, var. macropus; Peziza macropus var. hirta Pers., Ann. Bot. (Usteri) 15: 26. 1795; Helvella macropus (Pers.) P. Karst., Not. Sallsk. Fauna Fl. Fenn. Forh. 11: 224. 1870, var. macropus; Macroscyphus macropus (Pers.) Gray, Nat. Arr. Brit. Pl. 1: 672. 1821; Macropodia macropus (Pers.) Fuckel, Jahrb. Nassauischen Vereins Naturk. 23-24: 331.1870 (1869-1870); Aleuria macropus (Pers.) Gillet, Champ. France Discomyc.: 35. 1879; Lachnea macropus (Pers.) W. Phillips, Man. Brit. Disomyc.: 207. 1887; Cowlesia macropus (Pers.) Nieuwl., Amer. Midl. Naturalist 3: 300. 1916; Cyathipodia macropus (Pers.) Dennis, British Cup Fungi: 7. 1960.

Ascoma 30-40 mm high. Apothecia 4-6 mm high, 8-12 mm wide, cup-shaped when young, soon becoming disc or saucer-shaped, then nearly flattened saucer-shaped, margin incurved at first then expanded, typically with a distinct stipe; hymenium pale or dark gray when young, becoming pale greyish brown to dark brown with age, smooth to slightly wrinkled, ribs absent, dull, dry or moist; exterior surface pale gray to grayish brown, densely villose especially near the margin; margins of the apothecium curving over the hymenial surface when young. Stipe 15-35 mm long, 
1.5-4 mm broad, central, cylindrical, equal or enlarged at base, apex typically tapered, dry, solid, hairy-scurfy, densely pubescent, light dull-gray to gray-brown with a pale whitish base. Context whitish, very thin and fragile. Smell and Taste indistinct. Spore print white.

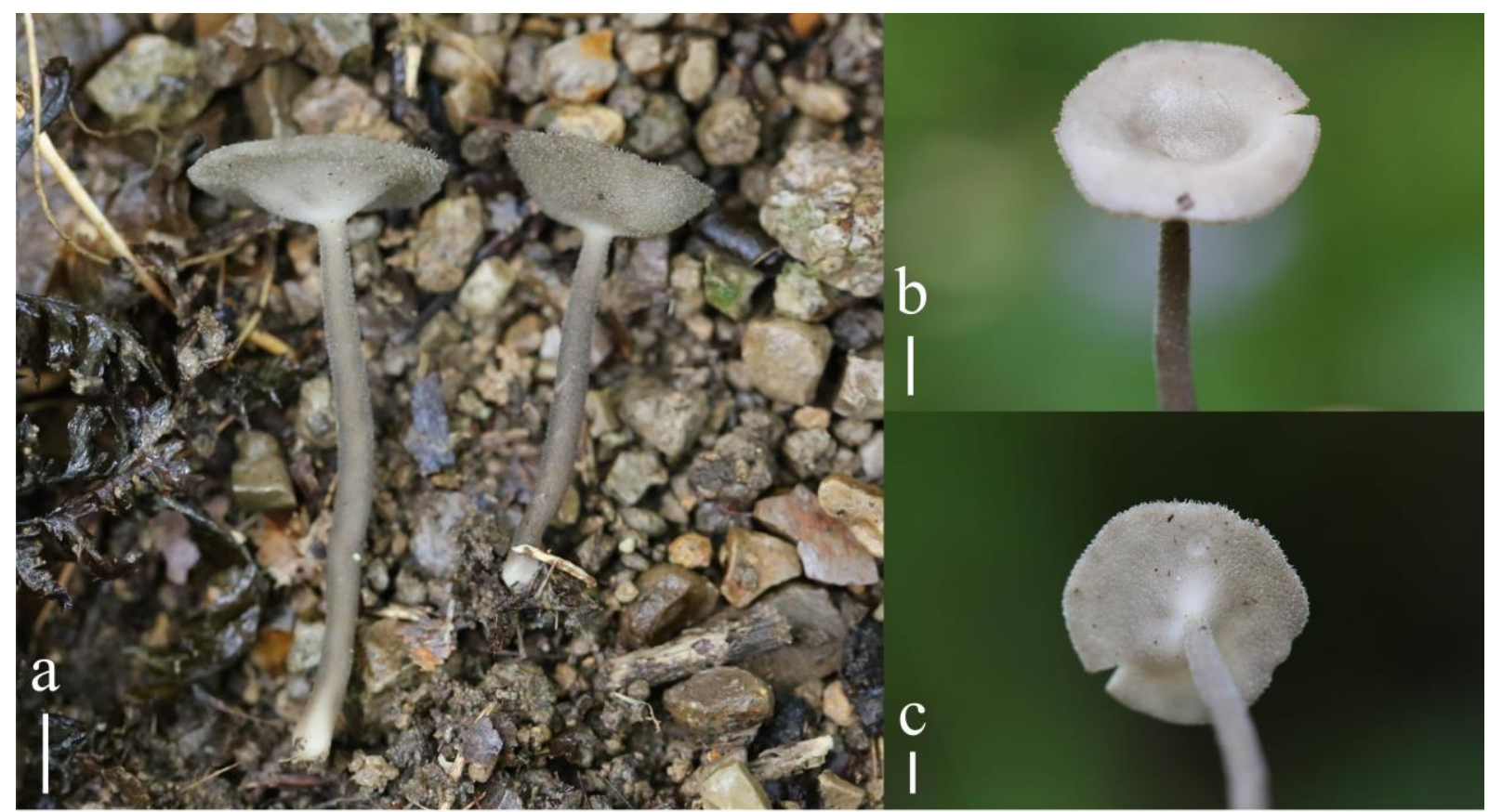

d

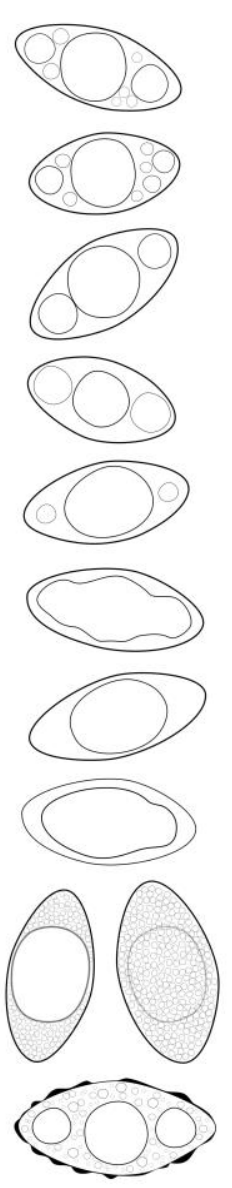

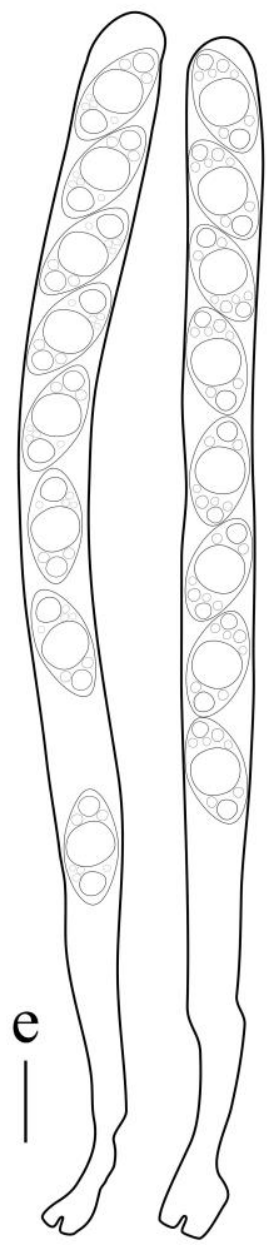
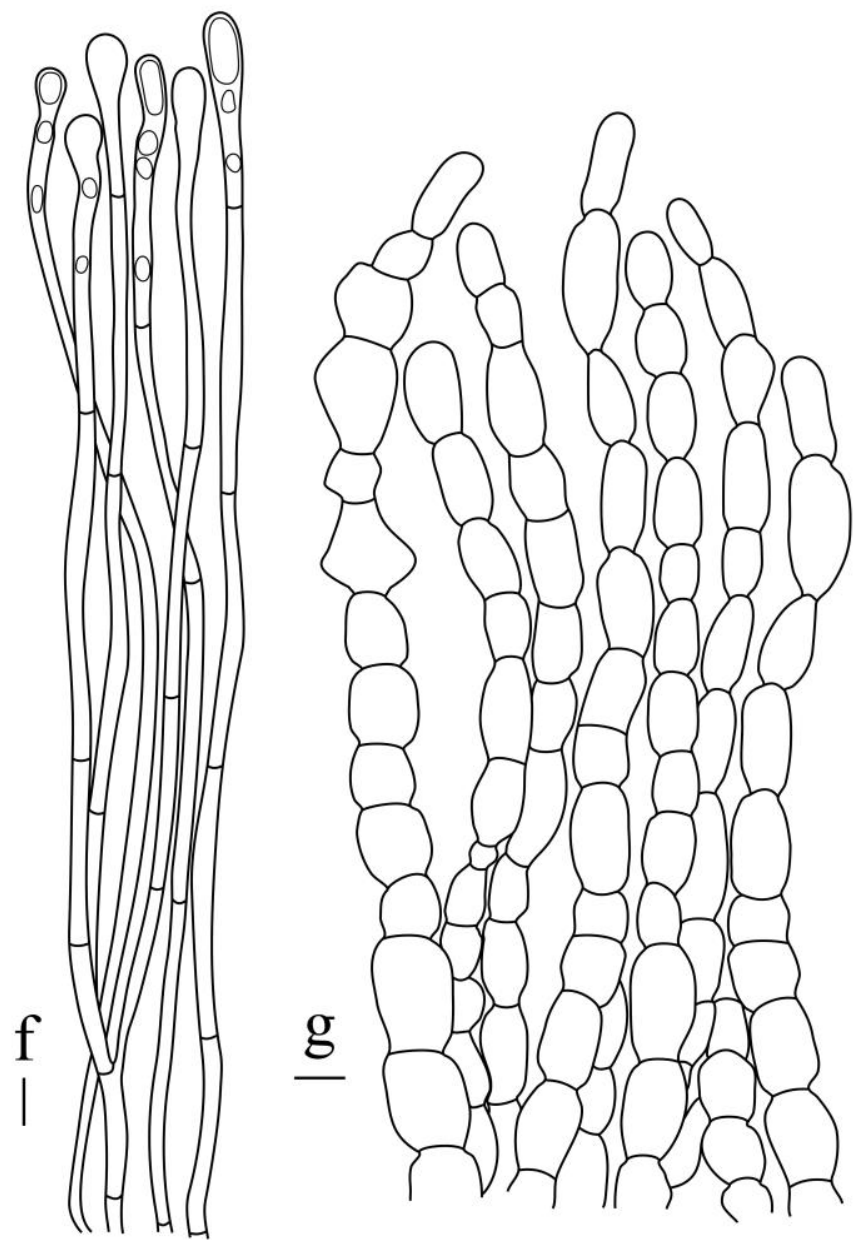

Fig. 3 - Helvella macropus (OKA2199): a - c Apothecia. d Ascospores. e Asci. f Paraphyses. $\mathrm{g}$ Ectal excipulum of apothecia. Scala bars: $\mathrm{a}=5 \mathrm{~mm}, \mathrm{~b}, \mathrm{c}=2 \mathrm{~mm}, \mathrm{~d}, \mathrm{e}=20 \mu \mathrm{m}, \mathrm{f}, \mathrm{g}=10 \mu \mathrm{m}$. Photographs and line drawings by O. Kaygusuz. 
Ascospores (18.0-)19.5-27.0(-29.0) $\times(9.6-) 10.0-12.2(-13.0) \mu \mathrm{m}, \mathrm{L}^{\mathrm{m}} \times \mathrm{W}^{\mathrm{m}}=23.0 \times 11.0$ $\mu \mathrm{m}, \mathrm{Q}=(1.7-) 1.9-2.3(-2.5) \mu \mathrm{m}, \mathrm{Q}^{\mathrm{m}}=2.1 \mu \mathrm{m}$, fusiform-elliptic to subfusiform, mostly with one large central oil droplet, usually finely punctate, smooth, hyaline, thin-walled. Asci 255-295 $\times$ 12.5-18.0 $\mu \mathrm{m}$, cylindrical, each ascus contains eight ascospores, inamyloid, uniseriate, hyaline, thin walled. Paraphyses $2-4 \mu \mathrm{m}$ wide, enlarged gradually to abruptly at the apex 5-9 $\mu \mathrm{m}$, clavate, slender, thin-walled, hyaline to pale brown, septate, contents finely granular. Medullary excipulum 180-260 $\mu \mathrm{m}$ broad, of textura intricata, composed of interwoven, branching, septate, hyaline, 3-5 $\mu \mathrm{m}$ broad hyphae. Ectal excipulum 210-290 $\mu \mathrm{m}$ broad, of textura angularis, hyaline, outermost cells $12-29 \times 10-17 \mu \mathrm{m}$, end cells cylindrical to subclavate, with long fascicled rows, slightly thick-walled.

Specimen examined - TURKEY, Artvin Province, Hopa district, near Çavuşlu town, on the edge of the Camellia sinensis L. garden, on moist to wet acidic soil rich in organic matter, elev. 300 m, 01.10.2015, coll. and det. by O. Kaygusuz, OKA2199 (MF228806, OKA-199).

Ecology - Solitary or gregarious from late September to early October, generally present at over $300 \mathrm{~m}$ of elevation, on the ground, among mosses, in temperate deciduous mixed forests, especially on acidic noncalcareous clay-loam soils. Reported also to grow under tea bushes (Camellia sinensis).

Comments - The species of the Helvella genus can generally be distinguished from one another by the dimensions, form, configuration and colour of the stipe and apothecia. Helvella macropus is characterized by a villose apothecia and stipe, and by verrucose ascospores.

$H$. macropus, $H$. fibrosa and $H$. cupuliformis show great similarity, but they differ from one another in colour and the morphology of their ascospores (see discussion under $\mathrm{H}$. fibrosa). Although $H$. macropus and $H$. terrestris (Velen.) Landvik share fusoid to subfusoid ascospores, the ascospore of $H$. macropus $(18-29 \times 9.6-13 \mu \mathrm{m})$ are smaller than those of $H$. terrestris $(50-65 \times$ 12-15 $\mu \mathrm{m}$, Landvik et al. 1999).

Morphologically H. macropus and H. brevis (Peck) Harmaja have similar features, however the ascospores of H. macropus are broader than those of H. brevis (Peck 1902, Weber 1972). Also, the stipe length of $H$. macropus is greater than that of H. brevis (8-16 mm long) (Harmaja 1974, Beug et al. 2014). Finally, the outside surface of the apothecia of $H$. brevis is much less villose than that of $H$. macropus.

Our phylogenetic analysis shows that $H$. macropus is phylogenetically closely related to but distinct from $H$. fibrosa, $H$. chinensis and $H$. cf. corium based on the ITS data. In addition, the result that $H$. macropus clustered with collections of $H$. macropus from South Korea and $H$. cf. macropus from China as a whole gets high statistical support, and 100\% bootstrap and 1.0 bayesian PP support. Similar phylogenetic results were observed by Landeros et al. (2015) and Skrede et al. (2017) in their phylogenetic analysis. H. macropus is presented from Turkey for the first time based on ITS data in this study. In future studies, it will be necessary to include analyses of sequences from Europe and other areas in order to determine the position of $H$. macropus in relation to other species.

In conclusion, our survey presents the new DNA sequences of the interesting and noteworthy species Helvella fibrosa and $H$. macropus. In addition, the nrITS sequence of $H$. fibrosa was uploaded to current databases by us for the first time as a result of this study. The two species studied were presented with detailed morphological descriptions, macro photographs and drawings of micro-structures. Our study confirms the existence in Turkey of certain uncommon and important fungi, and contribute to future studies on the phylogeny, morphology, taxonomy and distribution of the species recorded.

\section{Acknowledgements}

The authors would like to acknowledge the financial support of General Directorate of Agricultural Research and Policies, the Ministry of Agriculture and Forestry of the Republic of Turkey (TAGEM) (Project number: TAGEM14 /AR-GE/40). 


\section{References}

Abbott SP, Currah RS. 1997 - The Helvellaceae: systematic revision and occurrence in northern and northwestern North America. Mycotaxon 62, 1-125.

Akata I, Kaya A. 2012 - Two New Helvella Records for Turkish Mycobiota. Journal of Applied Biological Sciences 6, 31-33.

Bass D, Richards TA. 2011 - Three reasons to re-evaluate fungal diversity on Earth and in the ocean. Fungal Biology Reviews 25, 159-164.

Beug MW, Besette AE, Besette AR. 2014 - Ascomycete fungi of North America a mushroom reference guide. University of Texas Press, Austin.

Blackwell M. 2011 - The Fungi: 1, 2, 3 ... 5.1 Million Species? American Journal of Botany 98, 426-438.

Dissing H. 1966a - A revision of collections of the genus Helvella L. ex St-Amans emend. Nannf. in the Boudier Herbarium. Revue de Mycologie 31, 189-224.

Dissing H. 1966b - The genus Helvella in Europe with special emphasis on the species found in Norden. Dansk Botanisk Arkiv 25, 1-172.

Dorjey K, Kumar S, Sharma YP. 2013 - Four Helvella (Ascomycota: Pezizales: Helvellaceae) species from the Cold Desert of Leh, Ladakh, Jammu and Kashmir, India. Journal of Threatened Taxa 5, 3981-3984.

Gardes M, Bruns TD. 1993 - ITS primers with enhanced specificity for basidiomycetes. Application to the identification of mycorrhizae and rusts. Molecular Ecology 2, 113-118.

Hall TA. 1999 - BioEdit: A user-friendly biological sequence alignment editor and analysis program for Windows 95/98/NT. Nucleic Acids Symposium Series 41, 95-98.

Hansen K, Pfister DH. 2006 - Systematics of the Pezizomycetes-the operculate discomycetes. Mycologia 98, 1029-1040.

Hansen K, Schumacher T, Skrede I, Huhtinen S, Wang XH. 2019 - Pindara revisited - evolution and generic limits in Helvellaceae. Persoonia 42, 186-204.

Harmaja H. 1974 - Notes on the genus Helvella, including the merging of the genus Wynnella. Karstenia 14, 102-104.

Hawksworth DL. 1991 - The fungal dimension of biodiversity: magnitude, significance, and conservation. Mycological Research 95, 641-655.

Hawksworth DL. 2001 - The magnitude of fungal diversity: the 1.5 million species estimate revisited. Mycological Research 105, 1422-1432.

Hwang J, Zhao Q, Yang ZL, Wang Z, Townsend JP. 2015 - Solving the ecological puzzle of mycorrhizal associations using data from annotated collections and environmental samples an example of saddle fungi. Environmental Microbiology Reports 7, 658-667.

Katoh K, Standley DM. 2013 - MAFFT multiple sequence alignment software version 7: improvements in performance and usability. Molecular Biology and Evolution 30, 772-780.

Kaya A. 2009 - Macromycetes of Kahramanmaraş Province (Turkey). Mycotaxon 10, 31-34.

Kaygusuz O, Çolak ÖF, Türkekul İ. 2019 - Morchella tridentina (Ascomycota) from southwestern Turkey based on morphological and molecular evidences. Current Research in Environmental \& Applied Mycology 9, 103-112.

Kirk PM, Cannon PF, Minter DW, Stalpers JA. 2008 - Ainsworth and Bisby's Dictionary of the Fungi, 10th edn. CAB International, Wallingford, $771 \mathrm{pp}$.

Korf RP. 2008 - Nomenclatural notes. 12. Untangling Hedwig's Octospora villosa: Helvella fibrosa comb. nov. Mycotaxon 103, 307-312.

Kumar S, Stecher G, Li M. 2018 - MEGA X: molecular evolutionary genetics analysis across computing platforms. Molecular Biology \& Evolution 35, 1547-1549.

Landeros F, Iturriaga T, Rodríguez A, Vargas-Amado G, Guzmán-Dávalos L. 2015 - Advances in the phylogeny of Helvella (Fungi: Ascomycota), inferred from nuclear ribosomal LSU sequences and morphological data. Revista Mexicana de Biodiversidad 86, 856-871. 
Landvik S, Kristiansen R, Schumacher T. 1999 - Pindara: a miniature Helvella. Mycologia 91, 278-285.

Larsen H. 1980 - Key to the genera of the operculate cup-fungi (Pezizales) of the Pacific Northwest and Rocky Mountains Region. Pacific Northwest Key Counci 1-41.

Løken SB, Skrede I, Schumacher T. 2020 - The Helvella corium species aggregate in Nordic countries - phylogeny and species delimitation. Fungal Systematics and Evolution 5, 169186.

Miller MA, Pfeiffer W, Schwartz T. 2010 - Creating the CIPRES Science Gateway for inference of large phylogenetic trees. New Orleans, USA: Proceedings of the Gateway Computing Environments Workshop (GCE).

Nguyen NH, Landeros F, Garibay-Orijel R, Hansen K, Vellinga EC. 2013 - The Helvella lacunosa species complex in western North America: cryptic species, misapplied names and parasites. Mycologia 105, 1275-1286.

O’Brien HE, Parrent JL, Jackson JA, Moncalvo J-M, Vilgalys R. 2005 - Fungal community analysis by large-scale sequencing of environmental samples. Applied and Environmental Microbiology 71, 5544-5550.

Peck CH. 1902 - Report of the State Botanist. Bulletin of the New York State Museum 54, 931984.

Rambaut A. 2016 - FigTree: Tree figure drawing tool, version 1.4.3. Available from: http://tree.bio.ed.ac.uk/ (accessed: 01 April 2020).

Ronquist F, Teslenko M, van der Mark P, Ayres DL et al. 2012 - Mrbayes 3.2: Efficient Bayesian phylogenetic inference and model choice across a large model space. Systematic Biology 61, 589-542.

Sesli E, Denchev CM. 2008 - Checklists of the myxomycetes, larger ascomycetes, and larger basidiomycetes in Turkey. Mycotaxon 106, 65-67.

Skrede I, Carlsen T, Schumacher T. 2017 - A synopsis of the saddle fungi (Helvella: Ascomycota) in Europe - species delimitation, taxonomy and typification. Persoonia 39, 201-253.

Solak MH, Işıloğlu M, Kalmış E, Allı H. 2015 - Macrofungi of Turkey, Checklist, Vol. 2. Üniversiteliler Ofset, İzmir, Turkey.

Stamatakis A. 2014 - RAxML version 8: A tool for Phylogenetic Analysis and Post-Analysis of Large Phylogenies. Bioinformatics 30, 1312-1313.

Tibpromma S, Hyde KD, Jeewon R, Maharachchikumbura SSN et al. 2017 - Fungal diversity notes 491-602: taxonomic and phylogenetic contributions to fungal taxa. Fungal Diversity 83, 1261.

Uzun Y. 2019 - Helvella phlebophora, A New Ascomycete Record for Turkey. The Journal of Fungus 10, 159-162.

Van Vooren N. 2014 - Notes sur le genre Helvella L. (Ascomycota, Pezizales). 2. Les sous-genres Cupuliformes et Macropodes. Bulletin mycologique et botanique Dauphiné-Savoie 212, 29 47.

Wang YZ, Chen CM. 2002 - The Genus Helvella in Taiwan. Fungal Science 17, 11-17.

Weber NS. 1972 - The genus Helvella in Michigan. The Michigan Botanist 11, 147-201.

White TJ, Bruns T, Lee S, Taylor J. 1990 - Amplifications and direct sequencing of fungal ribosomal RNA genes for phylogenetics. In: Innis M, Gelfand D, Sninsky J, White T. (Ed.) PCR protocols: A Guide to Methods and Applications. Academic Press, New York, pp. 315322.

Wijayawardene NN, Hyde KD, Rajeshkumar KC, Hawksworth DL et al. 2017 - Notes for genera: Ascomycota. Fungal Diversity 86, 1-594.

Zhao Q, Tolgor B, Zhao Y, Yang ZL, Hyde KD. 2015 - Species diversity within the Helvella crispa group (Ascomycota: Helvellaceae) in China. Phytotaxa 239, 130-142. 